\title{
DANCE IN THE TREATMENT OF CHILDHOOD OBESITY: A PROPOSED PROTOCOL
}

\author{
A DANÇA NO TRATAMENTO DA OBESIDADE INFANTIL: PROPOSTA DE PROTOCOLO
}

Original Article

LA DANZA EN EL TRATAMIENTO DE LA OBESIDAD INFANTIL:PROPUESTA DEPROTOCOLO

Artigo OrIGINAL

Artículo Original

Camila de Paula Monteiro' (ID (Physical Education Professional) Mariana Luciano de Almeida² (DD (Gerontologist)

Carlos Roberto Bueno Júnior ${ }^{3}$ (ID (Physical Education Professional)

1. Universidade de São Paulo, Ribeirão Preto School of Physical Education and Sport (EEFERP-USP), Postgraduate Program in Physical Education and Sport, Ribeirão Preto, Sao Paulo, SP, Brazil. 2. Universidade de São Paulo, Ribeirão Preto School of Nursing (EERP-USP), Inter-unit Program of Doctoring in Nursing, Ribeirão Preto, Sao Paulo, SP, Brazil. 3. Universidade de São Paulo, Ribeirão Preto School of Physical Education and Sport (EEFERP-USP), Ribeirão Preto, Sao Paulo, SP, Brazil.

\section{Correspondence:}

Camila de Paula Monteiro

Escola de Educação Física

e Esporte de Ribeirão Preto (EEFERP-USP).

Av. Bandeirantes, 3900, Monte Alegre, Ribeirão Preto, São Paulo, Brazil. 14040-900.

capmonteiro@usp.br

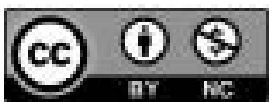

\section{ABSTRACT}

Introduction: Low levels of daily physical activity is considered to be one of the causes of the exorbitant increase in overweight and obese children, and associated comorbidities. Therefore, it is vital to develop strategies that will be implemented consistently, to improve this situation. Studies have used dance as a resource for training overweight and obese children, but the lack of information about the creation process and its respective stages reduce the possibility of these proposals being effectively applied. Objectives: To describe the steps in the creation of a dance protocol as a training resource, and its effectiveness in improving the health parameters of overweight and obese children. Methods: 30 children ( $9 \pm 1.1$ years) underwent training sessions consisting of a five-minute warm-up at $60 \%$ HRmax., and four 10-minute sessions at $70 \%$ to $80 \%$ at HRmax. interspersed with five 2-minute active recovery periods at $60 \% \mathrm{HRmax}$. The sessions were carried out three times a week, and lasted 60 minutes each, over a 13-week period. Before and after the training, the body composition, body mass index (BMI), BMI z-score, waist circumference (WC), waist-to-height ratio (WHtR), systolic (SBP) and diastolic (DBP) blood pressure and blood variables were measured. Statistical analysis was performed using a mixed effects regression model. Results: After training with Afro-Brazilian dance, there was a significant reduction $(p<0.05)$ in the BMI $z$-score and waist-to-height ratio. Conclusion: Afro-Brazilian dance training was a strategy with a positive effect on BMI z-score and waist-to-height ratio in overweight and obese children. Level of evidence IV; Case series.

Keywords: Child obesity; Dancing; Exercise.

\section{RESUMO}

Introdução: A diminuição da prática de atividade física diária é considerada uma das causas do aumento exorbitante de crianças com sobrepeso, obesidade e comorbidades decorrentes. Portanto, é de fundamental importância que estratégias que visem auxiliar na melhora desse quadro sejam desenvolvidas e implantadas de forma consistente. Os estudos têm utilizado a dança como recurso no treinamento de crianças com sobrepeso e obesidade, porém a falta de informação sobre o processo de criação e respectivas etapas diminui a possibilidade dessas propostas serem utilizadas de forma eficiente. Objetivos: Descrever as etapas da elaboração de um protocolo de dança como recurso de treinamento e sua eficácia em parâmetros de saúde de crianças com sobrepeso e obesidade. Métodos: Trinta crianças $(9 \pm 1,1$ anos) realizaram um treinamento que consistia em cinco minutos de aquecimento a $60 \%$ da FCmáx, quatro momentos de dez minutos de 70\% a 80\% da FCmáx intercalados com cinco momentos de dois minutos de recuperação ativa a $60 \%$ da FCmáx, $3 x / s e m, 60$ minutos por sessão, durante 13 semanas. Antes e após o treinamento foi realizada a avaliação da composição corporal, índice de massa corporal (IMC), z-score do IMC, circunferência da cintura (CC), relação cintura/estatura (RCE), pressão arterial sistólica (PAS) e diastólica (PAD) e variáveis sanguíneas. A análise estatística foi realizada utilizando o modelo de regressão de efeitos mistos. Resultados: Após o treinamento com danças afro-brasileiras houve redução significativa $(p<0,05)$ no $z$-score do IMC e na relação cintura/estatura. Conclusão: O treinamento com danças afro-brasileiras foi uma estratégia com efeito positivo sobre o z-score do IMC e relação cintura/estatura de crianças com sobrepeso e obesidade. Nível de evidência IV; Série de casos.

\section{Descritores: Obesidade infantil; Dança; Exercício.}

\section{RESUMEN}

Introducción: La disminución de la práctica de actividad física diaria es considerada una de las causas del aumento exorbitante de niños con sobrepeso, obesidad y comorbilidad resultantes. Por lo tanto, es de fundamental importancia que las estrategias que apunten a ayudar en la mejora de ese cuadro sean desarrolladas e implantadas de forma consistente. Los estudios han utilizado la danza como recurso en el entrenamiento de niños con sobrepeso y obesidad, pero la falta de información sobre el proceso de creación y respectivas etapas disminuye la posibilidad de que esas propuestas sean utilizadas de forma eficiente. Objetivos: Describir las etapas de elaboración de un protocolo de danza como recurso de entrenamiento y su eficacia en parámetros de salud de niños con sobrepeso y obesidad. Métodos: 30 niños $(9 \pm 1,1$ años) realizaron un entrenamiento que consistía en cinco minutos de calentamiento a 60\% de la FCmáx, cuatro momentos de diez minutos del 70\% a 80\% de la FCmáx intercalados con cinco momentos de dos minutos de recuperación activa a 60\% de FCmáx, 3x/semana, 60 minutos por sesión, durante 13 semanas. Antes y después del entrenamiento fue realizada la evaluación de la composición corporal, índice de masa corporal $(I M C)$, z-score del IMC, circunferencia de cintura (CC), relación cintura/estatura (RCE), presión arterial sistólica (PAS) y 
la diastólica (PAD) y variables sanguíneas. El análisis estadístico se realizó utilizando el modelo de regresión de efectos mixtos. Resultados: Después del entrenamiento con danzas afrobrasileñas hubo reducción significativa $(p<0,05)$ en el z-score del IMC y en la relación cintura/estatura. Conclusión: El entrenamiento con danzas afrobrasileñas fue una estrategia con efecto positivo sobre el z-score del IMCy relación cintura/estatura de niños con sobrepeso y obesidad.

\section{Nivel de evidencia IV; Serie de casos.}

Descriptores: Obesidad pediátrica; Baile; Ejercicio.

\section{INTRODUCTION}

Weight gain in infancy becomes more relevant as the years pass. In Brazil, data from the Brazilian Institute of Geography and Statistics (IBGE) show that one in every three children between five and nine years old is overweight or obese 1 . The physical and psychological consequences that result from this disease have been the focus of national and international studies ${ }^{2,3}$. Reducing sedentary behavior by practicing regular exercise can help in the process of decreasing the body mass index (BMI), thus providing better quality of life. Advances in this sense have helped researchers to investigate possible training types that are effective for children and adolescents ${ }^{4}$.

Recent studies use dancing as a form of exercise for obese children, resulting in metabolic improvements, in adhesion to practicing a more physically active life ${ }^{5,7}$, and in quality of life 7 . There are few dancing protocols described that can be reproduced due to a lack of detail about the process of building and executing them.

It is understood that with dancing it is also possible to develop cultural learning, and so it is interesting to incorporate knowledge of Brazilian culture into this context. Afro-Brazilian dances are widely known, however they are barely covered in infancy. For this culture to be positively uncovered, it is important to practice it daily. According to data from the Continuous National Household Sample Survey, published by the IBGE (2016), 55.4\% of the population of Brazil define themselves as brown (47.2\%) or black (8.2\%) the bodily experience, debating and recognizing the importance of this topic will consistently help in developing awareness in relation to inequalities and differences ${ }^{9}$.

In light of the above and considering the gaps that exist in the science, the aim of this study was to describe the stages in elaborating an Afro-Brazilian dancing protocol as an exercise resource for overweight and obese children and its effects on health parameters after a 13-week intervention.

\section{MATERIALS AND METHODS}

This is a longitudinal, quasi-experimental study, conducted in a municipality in the interior of São Paulo state. The research was approved by the Research Ethics Committee of the School of Physical Education and Sport of Ribeirão Preto of the University of São Paulo (CAAE 509757151.1.0000.5659) and by the Commission for Evaluating Research Projects of the Municipal Secretariat of Health of Ribeirão Preto.

30 children were recruited at basic health units and centers specialized in treating obese children in the municipality of Ribeirão Preto, SP, Brazil, in the period between June $1^{\text {st }}$ of 2016 and May $29^{\text {th }}$ of 2017. In addition, the project was promoted through posters, social media, phone calls, and home visits.

The parents or legal guardians of the children signed a free and informed consent form for the children to begin participating in the project and the children were also asked for verbal consent.

The inclusion criteria used were: children aged between 7 and 10 years old and presenting a medical certificate clearing them to perform physical exercise. The exclusion criteria were: presenting a medical condition, including joint problems, that could prevent them from carrying out the tests and training sessions; not having a legal guardian to accompany the training sessions; and having more than 25\% absence in the training sessions.

The music was previously selected and classified into three musical speeds (slow, moderate, and fast) according to the beats per minute (bpm), determined by a Wittner brand metronome, where a slow speed varied from $40 \mathrm{bpm}$ to $72 \mathrm{bpm}$, medium ranged from $73 \mathrm{bpm}$ to 120 bpm, and fast from $121 \mathrm{bpm}$ to $208 \mathrm{bpm}^{10}$.

The steps were arranged during the weeks of class according to their complexity, that is, the number of parts or components involved in mastering them, as well the informational processing required to execute them. The steps used during the training period were divided according to the rhythm involved (frevo, samba, or forró).

To compose the choreographies an addition method was used, in which the components of the task can be included gradually. After learning the first component of the ability (step), the second is included and both are executed. The other components follow the same proposal ${ }^{11}$. Thus, after 10 minutes the choreography was put together and being executed by everyone.

The warm-up lasted 5 minutes at 60\% maximum heart rate (HRmax), considering the maximum heart rate of the ergometric test carried out $^{12}$. The speed of the music used in this stage was slow. This phase was composed of recognizing the movements used during the main part of the class. The main part lasted 40 minutes at $70 \%$ to $80 \%$ maximum heart rate (HRmax), considering the maximum frequency of the ergometric test carried out ${ }^{12}$.

The musical speeds used in this stage were medium and fast. In this phase the choreographies were structured (addition method) and after 10 minutes they were executed, using all the steps that composed them.

Recovery lasted 10 minutes (divided into five 2-minute periods each) at 60\% maximum heart rate (HRmax). The musical speed used in this stage was slow. To compose this phase, the intervals between one choreography and another (Figure 1), one or two steps that composed the choreographies executed in the blocks were chosen and executed during the music at that moment. To guarantee that the children trained within the desired intensity during all the stages of the training sessions their heart rate was continuously monitored using the Polar Team² system (Finland).

All the evaluations were carried out in the weeks before and after the 13 weeks of physical training. To evaluate the participants' level of physical activity an adapted questionnaire was used evaluating physical activity and inactivity in children and adolescents. The questionnaire assesses the physical activities carried out and classifies the individuals based on the volume of physical activities practiced in the week prior to its application ${ }^{13}$.

\section{Somatic maturation (peak growth velocity)}

Peak growth velocity (PGV) is a resource for monitoring anthropometric variations, in which the age of the peak height growth velocity 


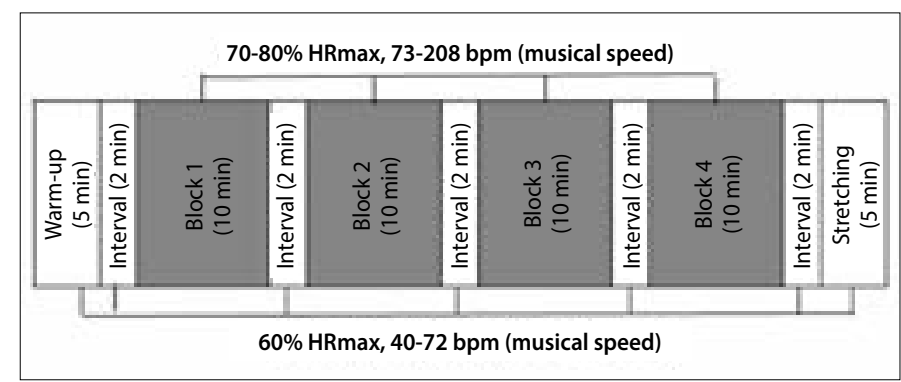

Figure 1. Structure of the training session.

is a very important indicator of maturation. This model considers brainstem height (sitting height in centimeters), leg height (stature minus brainstem height in centimeters), age (years), stature (cm), and body mass $(\mathrm{kg})^{14}$.

\section{Anthropometric and blood pressure evaluation}

Body mass was expressed in kilograms and height in centimeters, measured by a Welmy digital scale/stadiometer, model W200ALCD, with $0.1 \mathrm{~kg}$ and $0.01 \mathrm{~m}$ precision, respectively.

The height measure was carried out with the children standing, with their legs together, their heels, buttocks, and upper part of their backs against the scale, and their arms loose by their sides. They were orientated to hold the air in their lungs and their heads in the anatomical position - the Frankfurt Disease Control and Prevention plan ${ }^{15}$ was used as a reference.

After calculating the BMI given by body mass divided by height squared $\left(\mathrm{kg} / \mathrm{m}^{2}\right)$, and the age in full years and months, the data were plotted on z-score curves (BMI by age) for boys and girls between five and 19 years old, according to the reference values established by the World Health Organization².

The abdominal circumference measurement was made with a metric, non-elastic tape measure from Sanny", with $0.1 \mathrm{~mm}$ precision. The measure was taken with the children standing, at the end of expiration, with the tape positioned horizontally at the midpoint between the lower back arch and the iliac crest ${ }^{16}$.

For the body fat percentage analysis a bioelectrical impedance analysis (BIA) was carried out and a Maltron BF", model 906 device and disposable Sanny electrodes were used ${ }^{17}$. Blood pressure was evaluated using an Omron blood pressure monitor (model HEM-7113, Brazil) ${ }^{18}$.

\section{Lipid profile, glycaemia, insulin, and HOMA-IR}

For the glycaemia, insulin, and lipid profile analysis, blood was collected after 12 hours of fasting. The analyses were carried out by the Clinical Analyses Laboratory of the Faculty of Pharmaceutical Sciences of Ribeirão Preto of the University of São Paulo, in the biochemistry and hormones/immunology sector. The biological material was evaluated using a laboratory technique and BT 3000 plus self-analyzer device from Wiener Lab. The methods used were the enzymatic method for total cholesterol and triglycerides ${ }^{19}$, glucose ${ }^{20}$, and selective inhibition for cholesterol HDL. The plasmatic insulin dosage was analyzed at the same aforementioned laboratory and evaluated by a pharmacist and BT 3000 plus self-analyzer from Wiener Lab using the chemiluminescence method ${ }^{20}$.

\section{Ergometric test}

The ergometric test was carried out on a conveyor belt following the phased protocol validated for this age group, lasting from 8 to 12 minutes and continuously recording the heart rate using the Polar Team² system (Finland). The parents were told to dress the children in comfortable clothes for practicing physical exercises and when the children and parents or legal guardian arrived at the laboratory all of the test procedures were explained to them. The test was interrupted when the child was unable to continue exercising despite continuous verbal encouragement. Before conducting the test a familiarization session was carried out, also described in detail in the protocol, along with its velocities, inclinations, and criteria for the test to be considered the maximum ${ }^{12}$.

\section{Statistical analysis}

The result of each test was classified according to the tables of normative values and then analyzed using the SAS program (version 9.2), employing the PROC MIXED procedure. First an exploratory analysis of the data was carried out, described in means and standard deviations. Then the mixed effects linear regression model was used to evaluate the effect of the dance training protocol, considering a $5 \%$ level of significance.

\section{RESULTS}

90 possible participants were initially recruited. After home visits, telephone contact, clarifications about the stages of the project, and exclusions, 30 children managed to achieve at least 75\% presence in the training sessions and were kept in the analyses (Figure 2). The mean age was $9 \pm 1.1$ years old, the mean PGV was $1.73 \pm 0.99$ years, and the mean body mass was $54.60 \pm 15.86 \mathrm{~kg}$.

Tables 1 and 2 present the results of the linear regression relating to the anthropometric, clinical, and blood evaluations before and after the 13 weeks of Afro-Brazilian dance training.

According to the data presented, the height values, BMI z-score, and weight-to-height ratio (WHR) presented statistically lower values after the training period ( $p=<0.0001,0.0001$, and 0.002 , respectively) (Table 1).

The data contained in Table 3 show, in descriptive terms, a $41.3 \%$ $(\triangle \%)$ increase in the weekly time spent practicing physical activity and a $30.2 \%(\Delta \%)$ decrease in the time of no physical activity - there was a significant difference for both variables.

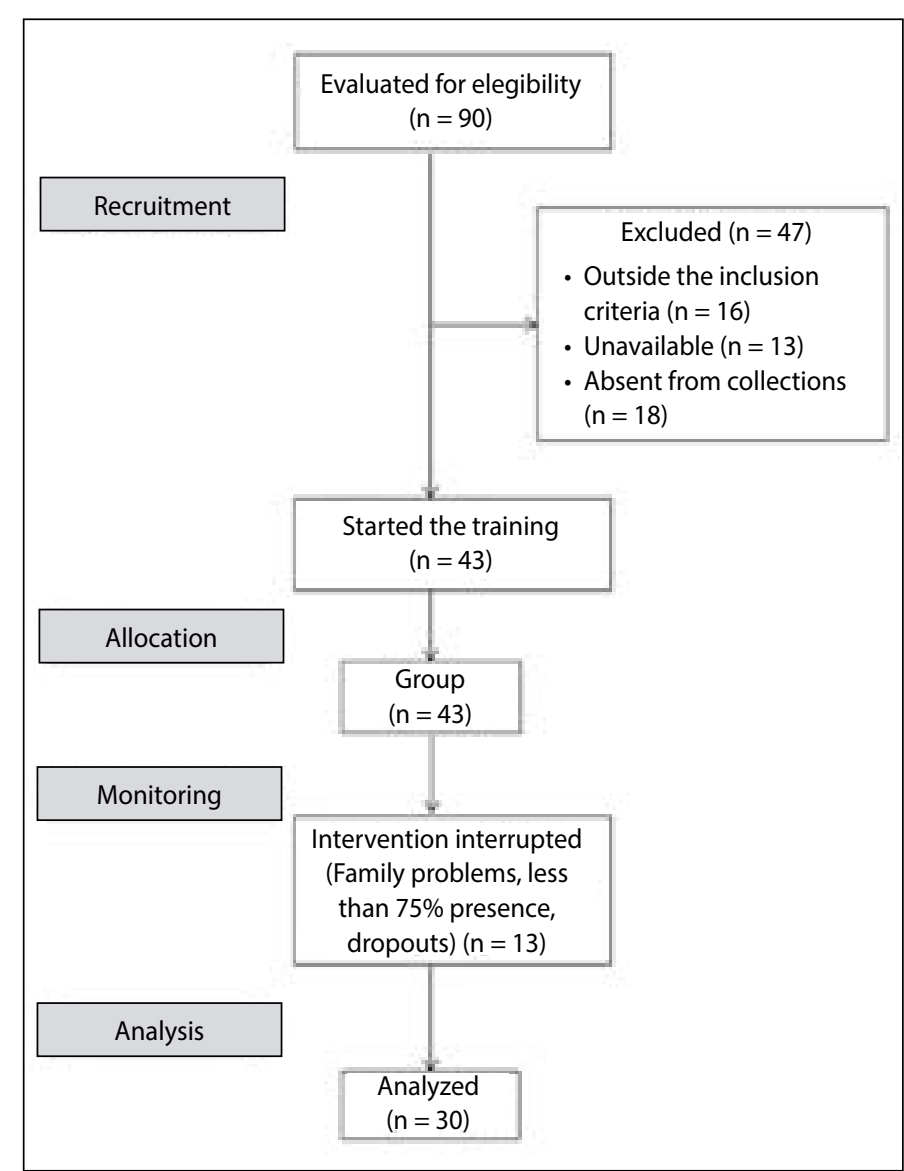

Figure 2. Flowchart of the experimental design. 
Table 1. Values relating to the anthropometric and clinical evaluations before and after 13 weeks of Afro-Brazilian dance training.

\begin{tabular}{c|c|c|c}
\hline Variable & Before & After & $\Delta \%$ \\
\hline Age (years) & $9.00(1.11)$ & $9.34(1.17)^{*}$ & 3.7 \\
\hline BM $(\mathrm{kg})$ & $54.6(15.86)$ & $55.08(16)$ & 0.08 \\
\hline Height $(\mathrm{m})$ & $1.40(0.10)$ & $1.43(0.10)^{*}$ & 2.1 \\
\hline BMI $\left(\mathrm{kg} / \mathrm{m}^{2}\right)$ & $27.27(4.86)$ & $27.52(4.97)$ & 0.09 \\
\hline BMl z-score & $3.18(0.74)$ & $2.97(0.78)^{*}$ & -6.6 \\
\hline SBP $(\mathrm{mmHg})$ & $105.07(12.68)$ & $106.20(12.21)$ & 1.1 \\
\hline DBP $(\mathrm{mmHg})$ & $63.20(6.41)$ & $67.87(9.77)$ & 7.3 \\
\hline HRrest (bpm) & $99.06(24.85)$ & $87.50(11.66)$ & -11.7 \\
\hline AC (cm) & $86.4(15.1)$ & $84(14.2)$ & -12.8 \\
\hline Waist-to-height ratio & $0.62(0.09)$ & $0.59(0.08)^{*}$ & -4.8 \\
\hline Fat (\%) & $37.37(4.51)$ & $36.45(5.23)$ & -2.4 \\
\hline BMR (kcal) & $1306.30(151.75)$ & $1328.73(158.70)$ & 1.7 \\
\hline
\end{tabular}

The data are presented as means (SDs). BM: Body mass; BMI: Body mass index; SBP: Systolic blood pressure; DBP: Diastolic blood pressure; HRrest: Resting heart rate; AC: Abdominal circumference; WHR: Waist-to-height ratio; BMR: Basal metabolic rate. ${ }^{*} p<0.05$ after versus before the intervention. Mixed effects linear regression model.

Table 2. Values relating to the blood evaluations before and after 13 weeks of Afro-Brazilian dance training.

\begin{tabular}{c|c|c|c}
\hline Variable & Before & After & $\Delta \%$ \\
\hline Triglycerides $(\mathrm{mg} / \mathrm{dl})$ & $89.20(43.63)$ & $96.07(51.44)$ & 7.7 \\
\hline HDL $(\mathrm{mg} / \mathrm{dl})$ & $47.63(10.16)$ & $46.57(10.07)$ & -2.2 \\
\hline LDL $(\mathrm{mg} / \mathrm{dl})$ & $106.79(27.89)$ & $104.52(22.2)$ & -2.1 \\
\hline Total cholesterol $(\mathrm{mg} / \mathrm{dl})$ & $172.27(31.89)$ & $170.30(27.74)$ & -1.1 \\
\hline Insulin $(\mu \mathrm{lU} / \mathrm{ml})$ & $15.35(9.55)$ & $15.01(9.07)$ & -2.2 \\
\hline Glucose $(\mathrm{mg} / \mathrm{dl})$ & $84.40(7.24)$ & $82.07(7.32)$ & -2.7 \\
\hline HOMA-IR & $3.31(2.22)$ & $3.27(2.31)$ & -1.2 \\
\hline
\end{tabular}

The data are presented as means (SDs). HDL: High density lipoprotein; LDL: Low density lipoprotein. Mixed effects linear regression model.

Table 3. Values relating to the time practicing physical activity before and after 13 weeks of Afro-Brazilian dance training.

\begin{tabular}{c|c|c|c}
\hline Variable & Before & After & $\Delta \%$ \\
\hline TWPE (min) & $\begin{array}{c}278.00 \\
(200.73)\end{array}$ & $\begin{array}{c}393.00 \\
(132.79)\end{array}$ & 41.3 \\
\hline TWNPE (min) & $\begin{array}{c}2246.86 \\
(4829.86)\end{array}$ & $\begin{array}{c}1566.32 \\
(1566.32)\end{array}$ & -30.2 \\
\hline
\end{tabular}

The data are presented as means (SDs). TWPE:Time with physical exercise; TWNPE: Time with no physical exercise. Mixed effects linear regression model.

\section{DISCUSSION}

This study aimed to verify the effects of 13 weeks of physical training involving Afro-Brazilian dances on the body mass, BMI z-score, waist circumference, waist-to-height ratio, fat percentage, basal metabolic rate, lipid profile, glycaemia, insulin, HOMA-IR, blood pressure, and resting heart rate of overweight or obese children.

According to the data presented in Table 1, no reduction in BMI and fat percentage was observed, however there was a significant reduction in BMI Z-score and WHR. In the study by Chrivia and collaborators ${ }^{21}$, despite a reduction in descriptive terms, there was no significant difference in BMI values before and after the training, which also occurred in the study developed by Klakk and collaborators ${ }^{22}$. This may be explained by the lower precision of the BMI percentage in identifying small alterations in body composition when compared to the $z$-score percentage. The study by Antunes and collaborators ${ }^{23}$ also showed a significant reduction in BMI z-score values after 20 weeks of concurrent training.

With relation to fat percentage, no statistically significant results were found in this sample. This result supports those of a study carried out in 10 state schools using 632 children between eight and 13 years old. The schools participating in the program added 4.5 hours to their school activities, divided into at least three days a week. No significant alteration was found in the fat percentage values, but there was a reduction in the prevalence of overweight and obese pupils after two years of intervention 22 .

The WHR value presented a significant improvement after the training period, indicating an improvement in the children's body composition and an attenuation of risk factors, since this is used as a body adiposity indicator and an increase in it is associated with higher blood pressure values ${ }^{24}$. A study carried out with children between six and nine years old in Brazil also showed the correlation between this measure and the presence of central obesity, as well as an anthropometric indicator associated with dyslipidemia ${ }^{25}$.

Regarding lipid profile, in this study there was no significant difference in the blood variables after the training period. A study carried out using children and adolescents subjected to a 20-week concurrent training protocol showed a significant reduction in $L D L$, triglyceride, and total cholesterol values ${ }^{23}$.

A study carried out in Kyoto (Japan) using obese (percentage higher than 95) children between 10 and 17 years old sought to investigate the influence of training sessions over eight weeks on stationary bicycles at 60 to $80 \%$ reserve heart rate. Their heart rate was monitored during the sessions, which lasted up to 25 minutes, aiming to evaluate a possible improvement in their physical aptitude and insulin resistance. The study revealed a significant reduction in $H O M A-I R$, but without significant values for glucose, with the HOMA-IR being related to the increase in cardiovascular aptitude ${ }^{26}$.

What may explain such divergences in the results, besides the difference in training carried out, volumes, and intensities, are the values of the variables investigated in this study being close to or within the normality values before the intervention.

According to the data presented in Table 3, after participating in the training program the weekly time practicing physical activities can increase by $41.3 \%$. These results support a study conducted with adolescents between 11 and 18 years old, which sought to evaluate the impact of dancing on the sedentary behavior of this population, with the use of accelerometers. The adolescents participated in at least one dance class per week at dance schools. The physical activity level was compared between the day on which the sample participated in the dance classes and the day on which they did not participate in the program ${ }^{7}$. At all the physical activity levels dancing caused a significant modification (light, moderate, and vigorous - 20.5\%, 31.2\%, and 42.6\%, respectively), resulting in an $8 \%$ reduction in general sedentary behavior $^{27}$. Finally, we recognize limitations in our study, such as the 3-month intervention time, meaning that our findings cannot be extrapolated to longer time intervals.

\section{CONCLUSION}

The elaboration of an Afro-Brazilian dance training protocol was described, which after 13 weeks was shown to have positive effects on health parameters of overweight and obese children, especially on BMI z-score and waist-to-height ratio.

\section{ACKNOWLEDGEMENTS}

To FAPESP (2013/21159-8) and CNPq (485045/2013-3) for their financial support.

All authors declare no potential conflict of interest related to this article 
AUTHORS' CONTRIBUTIONS: Each author made significant individual contributions to this manuscript. CPM: writing, revision, application of the training, statistical analysis, intellectual concept, preparation of the entire research project, and evaluations; MLA: critical review of the intellectual content and final approval of the manuscript; CRBJ: critical review of the intellectual content and final approval of the manuscript.

\section{REFERENCES}

1. Brasil. Instituto Brasileiro de Geografia e Estatística - IBGE. Pesquisa Nacional de Saúde do Escolar. Rio de Janeiro, 2016.

2. Macini MC. Associação Brasileira para o Estudo da Obesidade e da Síndrome Metabólica - Diretrizes brasileiras de obesidade. São Paulo: Compaygraf. 2016. p.126-58.

3. Kelley GA, Kelley KS, Pate, RR. Exercise and BMI z-score in overweight and obese children and adolescents: a systematic review and network meta-analysis of randomized trials. J Evid Based Med. 2017;10(2):108-28.

4. Meyer U, Schindler C, Zahner L, Ernst D, Hebestreit $H$, van Mechelen W, et al. Long-term effect of a school-based physical activity program (kiss) on fitness and adiposity in chindren: a cluster-randomized controlled trial. Plos One. 2014;9(2):e87929.

5. Beck S, Redding E, Wyon MA. Methodological considerations for documenting the energy demand of dance activity: a review. Front Psychol. 2015;6:568.

6. Zajenkowski M, Jankowski KS, Kołata D. Let's dance-feel better! Mood changes following dancing in different situations. Eur J Sport Sci. 2015;15(7):640-6.

7. O'Neill JR, Pate RR, Hooker SP. The contribution of dance to daily physical activity among adolescent girls. Int J Behav Nutr Phys Act. 2011;8(87):1-8.

8. Brasil. Instituto Brasileiro de Geografia e Estatística - IBGE. Indicadores IBGE. Pesquisa Nacional por Amostra de Domicílios Contínua Algumas características da força de trabalho por cor ou raça 2012/2016. 2016

9. Nunes C. A cultura de base africana e sua relação com a Educação escolar. Rev Metaf Educ. 2011;1(10):39-50.

10. Braga HO, Gonzáles Al, Stie, SW, Carvalho GM, Schmitt Netto A, Campos OA, et al. Protocolo de samba brasileiro para reabilitação cardíaca. Rev Bras Med Esporte. 2015;21(5):395-9.

11. Tani G. Aprendizagem motora: tendências, perspectivas e aplicações. Rev Pau Educ Fis. 2004;15(1):55-72.

12. Eisenmann JC, Guseman EH, Morrison K, Tucker J, Smith L, Stratbucker, W. Graded exercise testing in a pediatric weight management center: the De Vos Protocol. Child Obes. 2015;11(6):657-63.

13. Barbosa e Silva O. Questionários de Avaliação da Atividade Física e do Sedentarismo em Crianças e Adolescentes. Rev Derc. 2009:15(45):14-8.

14. Machado DR, Bonfim MR, Costa LT. Pico de velocidade de crescimento como alternativa para classificação maturacional associada ao desempenho motor. Rev Bras Cineantropom Desempenho Hum. 2009;11(1):14-21
15. Fonesca PH. Promoção e avaliação da atividade física em jovens brasileiros. São Paulo: Phorte; 2012.

16. Pazin DC, Rosaneli CF, Olandoski M, Oliveira ER, Baena CP, Figueredo AS, et al. Waist circumference is associated with blood pressure children with normal body mass index: a cross-sectional analysis of 3,417 school children. Arq Bras Cardiol. 2017;109(6):509-15.

17. Sant'Anna MS, Priore SE, Franceschini SEP. Métodos de avaliação da composição corporal em crianças. Rev Paul Pediatr. 2009;27(3):315-21.

18. Malachias MV, Póvoa RM Júnior, Nogueira AR, Souza D, Costa LS, Magalhães ME. 7th Brazilian Guideline of Arterial Hypertension. Chapter 3 - Clinical and complementary assessment. Arq Bras Cardiol. 2016;107(3 Suppl 3):14-7.

19. Warnick GR, Knopp RH, Fitzpatrick V, Branson L. Estimating low-density lipoprotein cholesterol by the Friedewald equation is adequate for classifying patients on the basis of nationally recommended cutpoints. Clin Chem. 1990;36(1):15-9.

20. Montenegro Neto PO. Diretrizes da Sociedade Brasileira de Diabetes 2017-2018. São Paulo: Clanaad, 2017.

21. Chrivia RA. Growth curves and Z-Score: sorting it all out. Neonatal Netw. 2012;31 (2):105-8.

22. Klakk H, Chinapaw M, Heidemann M, Andersen LB, Wedderkopp N. Effect of four additional physica education lesson on body composition in children aged 8-13 - a prospective study during two school years. Pediatrics. 2013;13:170

23. Antunes BM, Christofaro DG, Monteiro PA, Silveira LS, Fernandes RA, Mota J, et al. Effect of concurrent training on gender-specific biochemical variables and adiposity in obese adolescents. Arch Endocrinol Metab. 2015;59(4):303-9.

24. Vieira AV, Fonseca $\mathrm{PC}$, Andreoli CS, Pereira $\mathrm{PF}$, Hermsdorff $\mathrm{HH}$, Ribeiro $\mathrm{AQ}$, et al. A pressão arterial está associada a indicadores de adiposidade corporal em crianças de quatro a sete anos. Rev Port Cardiol. 2018;37(5):425-32.

25. Bila WC, Freitas AE, Galdino AS, Ferriolli E, Pfrimer K, Lamounier JA. Deuterium oxide dilution and bocy composition in overweight and obese schoolchildren aged 6-9 years. J Pediatr (Rio J). 2016;92(1):46-52.

26. Quadros TM, Gordia AP, Silva RC, Silva LR. Predictive capacity of anthropometric indicators for dyslipidemia screening in children and adolescents. J Pediatr. 2015;91(5):455-63.

27. McCormack SE, McCarthy MA, Harrington SG, Farilla L, Hrovat MI, Systrom DM, et al. Effects of exercise and lifestyle modification on fitness, insulin resistance, skeletal muscle oxidative phosphorylation and intramyocellular lipid content in obese children and adolescents. Pediatr Obes. 2014;9(4):281-91. 